\title{
The 2001 Recession: How Was It Different and What Developments May Have Caused It?
}

\author{
Kevin L. Kliesen
}

T he U.S. business expansion that started in March 1991 and ended exactly a decade later lasted more than a year longer than the previous record-long 1961-69 expansion. On July 17, 2003, the arbiters of U.S. business cycles (the National Bureau of Economic Research [NBER]) declared that the 2001 recession ended some time in November 2001. ${ }^{1}$ It was relatively short and, by some measures, shallow. Indeed, it bears some resemblance to the mild 1969-70 and 1990-91 recessions, which, respectively, followed the second- and third-longest expansions in U.S. history. Although the past two business cycles are consistent with the evidence that U.S. expansions have gotten progressively longer over time, and that recessions have become shorter, the mildness of the 2001 recession is perhaps surprising given the jarring economic developments that preceded it. In particular, the resiliency of the U.S. economy in the face of a boom and bust in U.S. equity markets and business outlays for capital equipment, as well as the economic disturbances caused by the fallout from the events of September 11, 2001, has been noted prominently by several policymakers and economists.

This article comprises two sections. The first section will discuss these developments in the context of the key differences between the 2001 recession and the "average" post-World War II recession. The second section will then attempt to ascertain, first, the extent to which forecasters were surprised by the recession and, second, what aspect of economic developments in the latter part of the 1990s and into 2000-01 surprised them. I accomplish the latter by examining forecast errors for real gross domestic product (GDP) growth and some of its major components from a macroeconometric fore-

\footnotetext{
1 See < http://www.nber.org/cycles/july2003.html > . In an article published in April 2003, this was also the date chosen by Chauvet and Piger (2003) using a type of Markov-switching model that was originally developed by Hamilton (1989).

Kevin L. Kliesen is an economist at the Federal Reserve Bank of St. Louis. The author thanks William Gavin, William Poole, and Daniel Thornton for helpful comments. Thomas Pollmann provided research assistance.

(1) 2003, The Federal Reserve Bank of St. Louis.
}

casting model. Such an exercise may help determine whether some sector-specific shocks can be identified as potential causes for the recession.

\section{COMPARING THE 2001 RECESSION WITH PREVIOUS POSTWAR RECESSIONS}

According to the NBER's Business Cycle Dating Committee, which establishes and maintains the chronology of U.S. business cycles, the average recession (defined as the time from the peak to the trough) lasted 11 months during the post-World War II period. ${ }^{2}$ The shortest of these downturns has lasted 6 months (1980), while the longest have lasted 16 months (1973-75 and 1981-82). Eliminating these extremes shows that recessions tend to average about 9 months. Hence, the 2001 recession, which ended in November 2001, was somewhat shorter than average.

The 2001 recession's relatively short duration is not the only unique characteristic that distinguishes it from other post-World War II recessions. ${ }^{3}$ Another unique feature was its mildness, as seen by the decline in output (real GDP). Current national income and product account (NIPA) data indicate that real GDP rose 0.2 percent from the first quarter of 2001 (the peak quarter designated by the NBER Committee) to the fourth quarter of 2001 (the trough quarter according to the NBER). Economists have found that the severity of the recession importantly influences the magnitude of the recovery. That is, a deep recession tends to be followed by a strong recovery, but a mild recession tends to be followed by a mild recovery. ${ }^{4}$ But does the length of the expansion say anything about the duration of the recession? Perhaps.

One notable characteristic of the 2001 recession

\footnotetext{
2 See $<$ http://www.nber.org/cycles $>$

3 Others who have noted the uniqueness of the 1991-2001 business cycle include Koenig, Siems, and Wynne (2002), Lansing (2003), and Nordhaus (2002).

4 See Friedman (1964) or Balke and Wynne (1996).
} 


\section{Table 1}

Economic Performance During Recessions Following the Three Longest Expansions and All Other Post-World War II Expansions

\begin{tabular}{|c|c|c|c|c|c|c|}
\hline \multicolumn{4}{|c|}{ Expansion and contraction dates as determined by the NBER } & \multicolumn{3}{|c|}{ Recession performance* } \\
\hline $\begin{array}{l}\text { Expansion } \\
\text { dates }\end{array}$ & $\begin{array}{l}\text { Expansion length } \\
\text { (months) }\end{array}$ & $\begin{array}{c}\text { Contraction } \\
\text { dates }\end{array}$ & $\begin{array}{l}\text { Contraction } \\
\text { length }\end{array}$ & Real GDP & $\begin{array}{c}\text { Nonfarm } \\
\text { employment }\end{array}$ & $\begin{array}{l}\text { Unemployment } \\
\text { rate }\end{array}$ \\
\hline $3 / 91-3 / 01$ & 120 & $3 / 01-11 / 01$ & 8 & -0.62 & -1.34 & 2.10 \\
\hline $2 / 61-12 / 69$ & 106 & $12 / 69-11 / 70$ & 11 & -0.61 & -1.47 & 2.70 \\
\hline $11 / 82-7 / 90$ & 92 & $7 / 90-3 / 91$ & 8 & -1.49 & -1.63 & 2.80 \\
\hline $\begin{array}{l}\text { A. Average, } \\
\text { three longest }\end{array}$ & 106.0 & & 9.0 & -0.91 & -1.48 & 2.53 \\
\hline $3 / 75-1 / 80$ & 58 & $1 / 80-7 / 80$ & 6 & -2.19 & -1.45 & 2.2 \\
\hline $10 / 49-7 / 53$ & 45 & $7 / 53-5 / 54$ & 10 & -2.72 & -3.47 & 3.6 \\
\hline 5/54-8/57 & 39 & $8 / 57-4 / 58$ & 8 & -3.71 & -4.32 & 3.8 \\
\hline $10 / 45-11 / 48$ & 37 & $11 / 48-10 / 49$ & 11 & -1.67 & -5.22 & 4.5 \\
\hline $11 / 70-11 / 73$ & 36 & $11 / 73-3 / 75$ & 16 & -3.40 & -2.89 & 4.4 \\
\hline 4/58-4/60 & 24 & $4 / 60-2 / 61$ & 10 & -1.59 & -2.30 & 2.3 \\
\hline $7 / 80-7 / 81$ & 12 & $7 / 81-11 / 82$ & 16 & -2.86 & -3.02 & 3.6 \\
\hline $\begin{array}{l}\text { B. Average, } \\
\text { all other post-1945 }\end{array}$ & 35.9 & & 11.0 & -2.59 & -3.24 & 3.49 \\
\hline $\begin{array}{l}\text { Percentage } \\
\text { difference (A/B) }\end{array}$ & 195.3 & & -18.2 & -64.9 & -54.3 & -27.5 \\
\hline
\end{tabular}

Test of correlation between long expansions and short recessions:

Spearman rank-order test statistic

$$
-1.95
$$

Test whether percentage differences (A/B) are statistically significant:

Wilcoxon rank-sum test statistics

$\begin{array}{lll}6 & 8 & 10\end{array}$

NOTE: November 2001 (fourth quarter) was the trough of the 2001 recession. A Spearman rank-order test statistic of 1.86 is significant at the 10 percent level. A Wilcoxon rank-sum test statistic of 6 is significant at the 2 percent level; a test statistic of 8 is significant at the 10 percent level.

*Percentage change from "local"-designated peak to trough for real GDP and nonfarm payroll employment. Unemployment rate is percentage point change from peak to trough.

was that it followed a record-long U.S. expansion. Indeed, the 1990-91 recession, which lasted 8 months, interrupted the nearly 18 years of continuous economic expansion that has been characterized as The Long Boom. ${ }^{5}$ As seen by the critical value of the Spearman rank-order test statistic in Table 1 (significant at the 10 percent level), there is some

\footnotetext{
5 See Taylor (1998).
}

evidence that long expansions tend to be followed by short recessions rather than long recessions. ${ }^{6}$ The average of the three longest post-World War II economic expansions was 106 months, compared

\footnotetext{
6 The Spearman rank-order test ranks the expansions and contractions from longest to shortest. (Ties are assigned values of 0.5 ; for example, the two longest recessions of 16 months each receive a ranking of 1.5 . The null hypothesis is that there is no correlation between the ranking of expansions and contractions. See < http://www.nr.com > .
} 
with nearly 36 months for all other post-World War II expansions. The average recession following the three longest expansions was 9 months, a little more than 18 percent shorter than all others.

Since the NBER uses monthly measures of economic activity to date peaks and troughs, their trough quarters do not always correspond to actual peaks and troughs of aggregate output. ${ }^{7}$ Table 1 also shows that the actual peak-to-trough percentage decline in real GDP during the recessions following the three longest expansions was about 1 percent, versus 2.6 percent for all other post-World War II recessions. Moreover, the percentage decline in nonfarm employment and the percentage-point rise in the unemployment rate following the three longest expansions were about, respectively, 54 and 28 percent smaller than in the recessions that followed the other seven expansions. There is some statistical evidence that recession performance varies with the length of the business expansion. According to the Wilcoxon rank-sum test statistic reported in Table 1, the average percentage changes in real GDP and nonfarm payroll employment in recessions that followed the three longest recessions are significantly different from the average changes that followed all other expansions. The average change in the unemployment rate, however, is not statistically different in recessions following long or short expansions. ${ }^{8}$

The evidence presented in Table 1 suggests that recessions that follow long expansions tend (i) to be of shorter duration and (ii) to have smaller-thanaverage declines in output and payroll employment. The finding that recessions are milder after long expansions, which runs counter to Friedman (1964), might be that fewer imbalances accumulate over the course of long expansions, whereas expansions of a shorter duration end because of oil price shocks or an increase in inflation that exacerbates distortions to the price mechanism, thereby precipitating "tightening" actions by monetary policy policymakers. Over the final four quarters prior to the peak of the three longest expansions reported in Table 1, the consumer price index (CPI) inflation rate aver-

\footnotetext{
7 For example, the NBER declared that the 2001 peak occurred in March (2001:Q1); however, real GDP actually peaked one quarter earlier (2000:Q4).

8 The Wilcoxon rank-sum test is a nonparametric test. In this instance, the sum of the ranks for the percentage change in real GDP, nonfarm employment, and the unemployment rate are ranked from smallest to largest $(\mathrm{N}=10)$ and classified as whether they occurred in the three longest recessions or the remaining seven recessions. The test statistic is simply the sum of the ranks of the longest recessions. See $<$ http://www.stat.auckland.ac.nz/ wild/ChanceEnc/ >
}

aged about 4.5 percent; over the final four quarters of the remaining expansions, the inflation rate averaged 6.3 percent.

Table 2 details how several other important economic indicators fared during the 2001 recession relative to their postwar average. First, because of its relative mildness, the decline in nonfarm employment was well below average and the civilian unemployment rate rose by less than normal. Second, growth of real disposable personal income was stronger than normal, which helped to keep consumer spending growth at elevated rates. Strong growth of real disposable personal income reflected above-average growth of nonfarm labor productivity. The latter development also helped to restrain aggregate price pressures. Third, in contrast with previous recessions in which the stock market had started to rally before the trough, equity prices continued to fall throughout the 2001 recession, which helped to put downward pressure on business fixed investment (by raising the equity cost of capital). ${ }^{9}$ Fourth, the decline in private inventory investment was the largest of any post-World War II recession. Finally, real exports during the 2001 recession fell by a much-greater-than-average amount. In particular, exports of capital goods to several important Asian markets fell sharply.

Ultimately, recessions occur because of economic developments that are of sufficient magnitude to alter expenditures by households and firms, thereby reducing aggregate demand, output, and employment. Accordingly, the causal factors behind various recessions may differ. Many economists have documented the role of international disturbances, technology shocks, energy price shocks, and actions taken by monetary policymakers to restrain an unanticipated rise in the general price level. ${ }^{10}$

The next section of the paper will discuss some of the developments that unfolded over the course of 1999 to 2001 that either mitigated or exacerbated the severity of the recession. The paper employs a well-known macroeconometric forecasting model to look at several developments that appear to have had a hand in shaping economic developments prior to and during the 2001 recession. Large forecast errors may reveal the unanticipated shocks that hit the U.S. economy during this period. Among the developments that will be discussed are the boom and bust in U.S. equity markets, the sharp decline

\footnotetext{
9 Equity prices are measured as end-of-period values, rather than quarterly averages.

${ }^{10}$ For example, see Fuhrer and Schuh (1998) or Zarnowitz (1992).
} 


\section{Table 2}

\section{Growth of Various Economic Series During Post-World War II Recessions (Percent Change)}

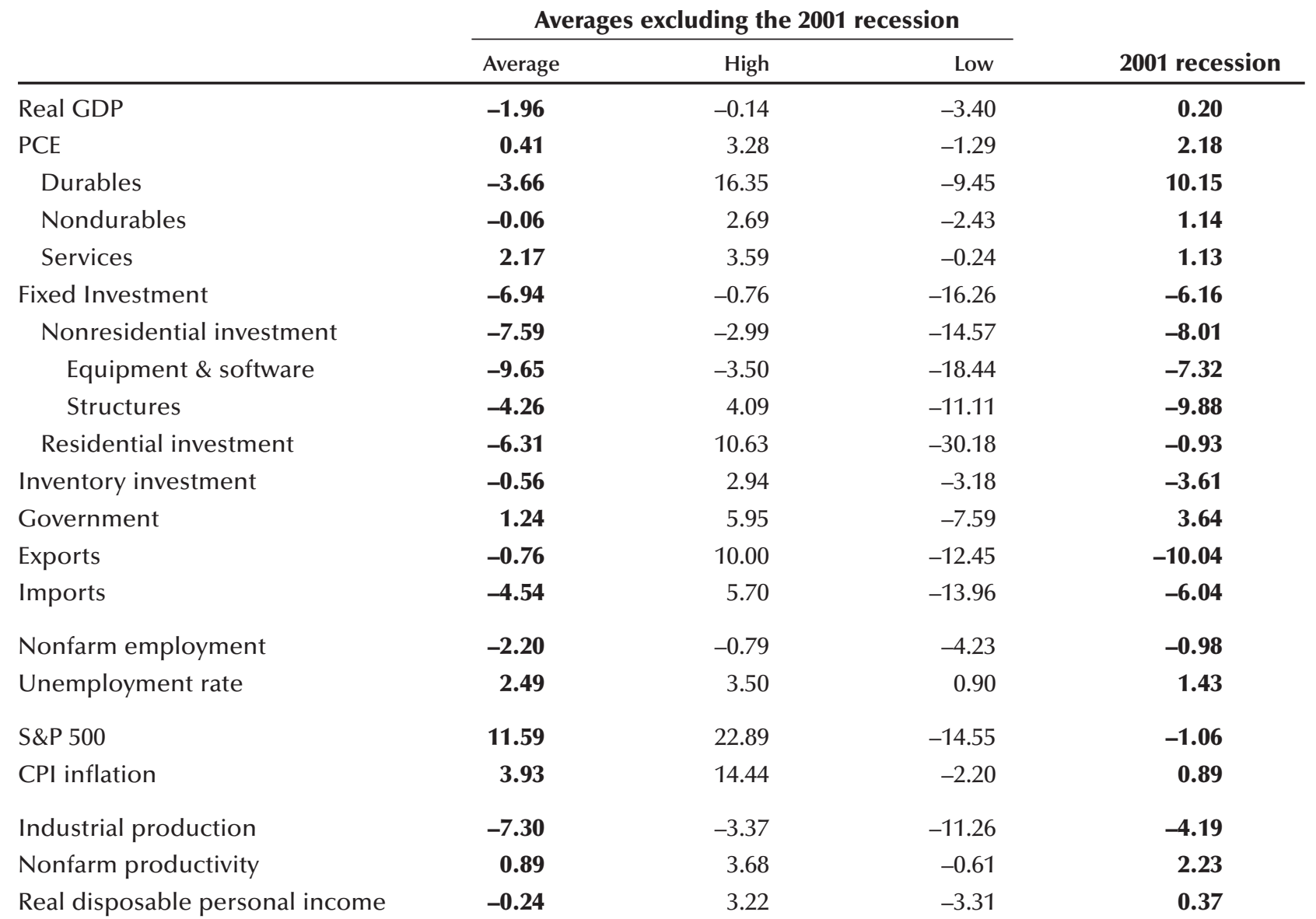

NOTE: Period for the 2001 recession is 2001:Q1 to 2001:Q4. Percent changes are from NBER-designated peak quarters to NBERdesignated trough quarters. Change in the unemployment rate is in percentage points.

in business capital expenditures for computers and software, the economic fallout from the events surrounding September 11, and the significant decline in the real value of U.S. exports.

\section{WERE FORECASTERS SURPRISED BY THE RECESSION?}

Finding the causes of the 2001 recession, or any recession, is often extremely difficult. ${ }^{11}$ In the literature, finding the proximate cause (or shock) that precipitated a downturn in economic activity has taken many forms. ${ }^{12}$ This article uses a large-

\footnotetext{
${ }^{11}$ See Boldin (1994).

${ }^{12}$ These have included the identification of shocks, using vector auto
}

scale macroeconometric forecasting model to identify structural changes in the U.S. economy. Specifically, I examine quarterly forecasts that are published in the last month of each quarter in the Blue Chip Economic Indicators (BCEI). ${ }^{13}$ These are known as the Blue Chip Econometric Detail (BCED). ${ }^{14}$

regression (VAR) or real business cycle models, to changes in the major components of real GDP relative to trend. See Walsh (1993), Blanchard (1993), Hansen and Prescott (1993), and Hall (1993).

13 The BCED are published in March (Q1), June (Q2), September (Q3), and December (Q4).

14 Because no model is used to produce the Blue Chip Consensus forecast, the $B C E D$ uses Macroeconometric Advisers' macroeconometric model to produce detailed quarterly forecasts of output, prices, interest rates, profits, productivity, and other economic series. The $B C E D$ forecasts are based on the Blue Chip Consensus forecast. 
Forecasters were surprised by the onset of the recession. Table 3 shows that, up until the September 11, 2001, terrorist attacks, Blue Chip forecasters generally believed that the odds of the U.S. economy falling into a recession within the next 12 months were fairly low. Although the percentage of those expecting a recession to develop within a year's time reached a high of 38 percent in April 2001, nearly nine in ten forecasters as of September 10, 2001, did not believe that the United States was in a recession. According to Figure 1, which plots the estimate of real GDP growth for the quarter in which the $B C E D$ is published (current-quarter forecast), Blue Chip forecasters were surprised by the strength of aggregate economic growth over the first two quarters of 2000 , as seen by the relatively large currentquarter forecast errors for those two quarters. Over four of the next five quarters, though, forecasters over-estimated the strength of real economic growth - as seen by the real-time estimates of quarterly real GDP growth published in the BCED. ${ }^{15}$ After September 11, forecasters expected a decline in output in the fourth quarter of 2001, as published in the December 2001 (2001:Q4) forecast. However, as seen by the relatively large negative forecast error (forecast less actual), this did not occur.

The difficulty with these macroeconomic analyses after the fact is that history is constantly being rewritten-especially, in this case, through the annual revisions that occur to the NIPA data published by the Bureau of Economic Analysis. NIPA data published in real time in Figure 1 showed that actual real GDP growth turned negative in only one quarter during this period: the third quarter of 2001. But, as seen in the boxed insert, the 2002 revisions were especially significant: With their publication in July 2002, real GDP was estimated to have declined in the first, second, and third quarters of 2001. Hence, one reason why the 2001 recession may have caught forecasters by surprise is that the real-time data offered little support for such a conclusion, which is why many forecasters viewed the NBER's decision in November 2001 to date the peak of the 1991-2001 business expansion in March 2001 as somewhat of a surprise (Table 3).

\section{IDENTIFYING AND EVALUATING FORECAST SURPRISES}

The abrupt switch from negative (underpredicted) to mostly positive (over-predicted) real

\footnotetext{
${ }^{15}$ See footnote to Table 4 for a description of the timing of the currentquarter forecast and the real-time estimates.
}

Table 3

Recession Probabilities According to Blue Chip Forecasters, 2000-01 (Percent)

\begin{tabular}{|c|c|c|}
\hline \multirow[b]{2}{*}{ Date } & \multicolumn{2}{|c|}{$\begin{array}{c}\text { Question posed: } \\
\text { "What Are the Odds } \\
\text { a Recession Will Begin Within..." }\end{array}$} \\
\hline & 12 months & 24 months \\
\hline May 2000 & 18 & 33 \\
\hline June 2000 & 18 & 33 \\
\hline July 2000 & 19 & 31 \\
\hline August 2000 & 18 & 31 \\
\hline September 2000 & 16 & 29 \\
\hline November 2000 & 23 & $\mathrm{~N} / \mathrm{A}$ \\
\hline April 2001 & 38 & $\mathrm{~N} / \mathrm{A}$ \\
\hline \multirow[t]{2}{*}{ May 2001} & 32 & $\mathrm{~N} / \mathrm{A}$ \\
\hline & \multicolumn{2}{|c|}{$\begin{array}{l}\text { Question posed: } \\
\text { "Has the U.S. } \\
\text { Slipped Into a Recession?" }\end{array}$} \\
\hline Date & Yes & No \\
\hline February 2001 & 5 & 95 \\
\hline June 2001 & 7 & 93 \\
\hline July 2001 & 13 & 87 \\
\hline August 2001 & 15 & 85 \\
\hline September 10, 2001 & 13 & 87 \\
\hline September 19, 2001 & 82 & 18 \\
\hline
\end{tabular}

NOTE: On November 26, 2001, the NBER Business Cycle Dating Committee determined that the business cycle peak occurred sometime in March 2001.

SOURCE: $B C E I$, various issues.

GDP forecast errors in the third quarter of 2000 suggests when the shock may have occurred. To help sort through this issue, Table 4 lists the currentquarter forecast from the $B C E D$, the real-time estimate as published in the subsequent $B C E D$, and the current-quarter forecast error (the difference between the two). In addition to the growth of real GDP, I look at the growth of real personal consumption expenditures (PCE), real business (nonresidential) fixed investment, real residential fixed investment (RFI), and real net exports (in billions of 1996 chaintype dollars), nonfarm labor productivity, and the GDP chain-type price index. This section will discuss the pattern of forecast errors for these major econ- 


\section{Real GDP Growth: Current-Quarter Forecast and Forecast Error and Real-Time Actual Growth Estimate}

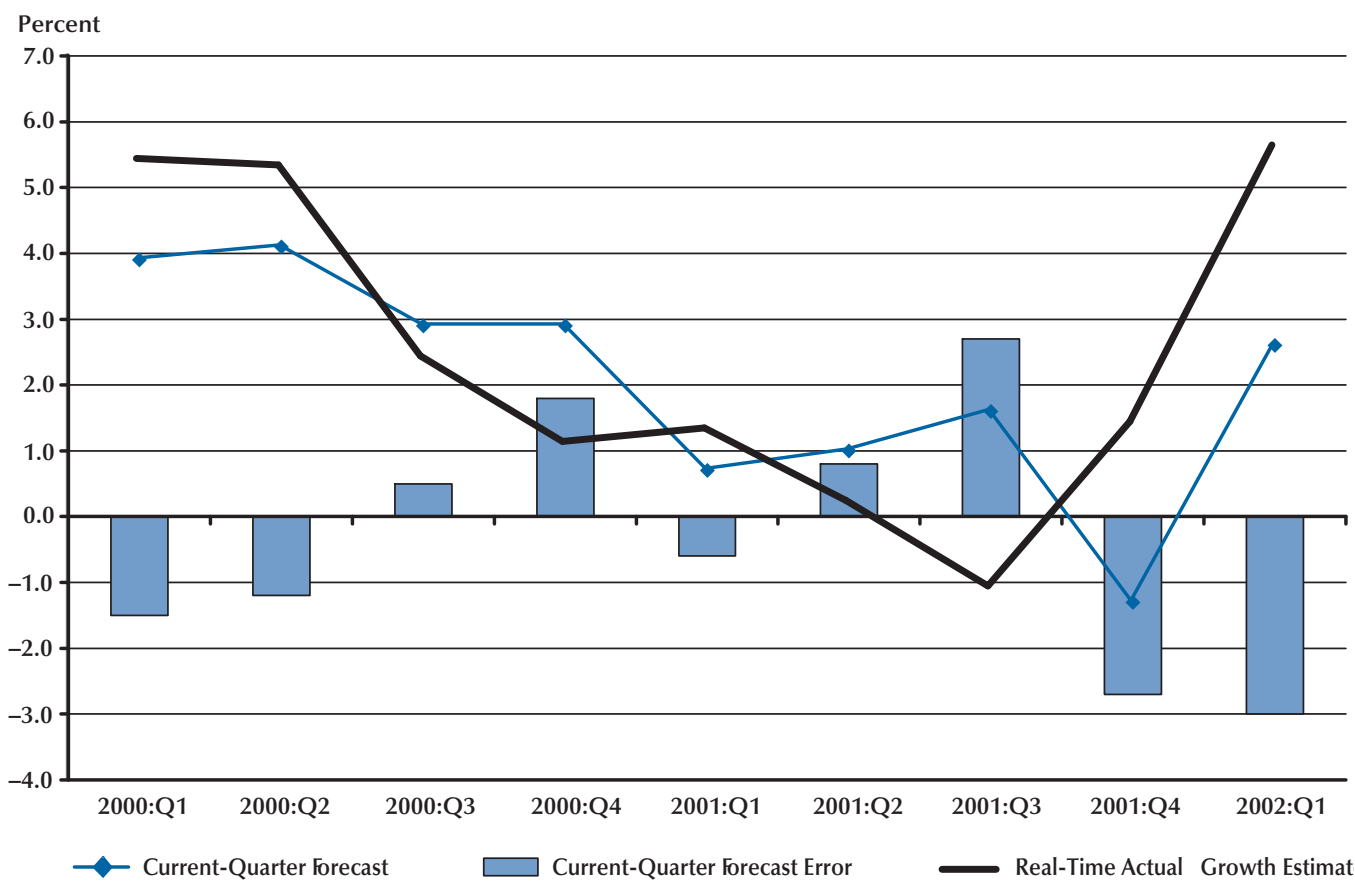

omic variables in the context of the macroeconomic developments noted above. From this discussion, it is hoped that some identification of the likely shocks that caused the 2001 recession will emerge.

\section{Consumer Spending}

As seen in Table 2, real PCE usually increases slightly (about 0.5 percent) during the average postwar recession. This was true for the 2001 recession as well, but the increase in real PCE was relatively large (2.2 percent). On average, the pattern of consumer expenditures by type of good and service during a recession is quite different: Spending on consumer durables typically falls about 3.75 percent, while spending on services increases by a little less than 2.25 percent. Real expenditures on nondurable goods is about unchanged. Even though consumer expenditures on durables tends to fall sharply, the relative income inelasticity of consumer demand for services, combined with the fact that household spending on services (current dollars) is now a little more than 59 percent of PCE (versus roughly 41 percent in 1960), probably explains why total spend ing does not appreciably decline. ${ }^{16}$
On average, consumer expenditures on durable goods peak about two quarters prior to the business cycle peak; they then bottom out about one quarter after the trough. After showing relatively weaker growth in 2000 and early 2001, consumer durable goods purchases rose strongly well into the 2001 recession. The 10.2 percent increase for real consumer durables during the 2001 recession was surpassed only by the 1948-49 recession. Table 4 shows that forecasters generally were surprised by the strength of real PCE growth prior to and into the recession, which suggests that a shock to consumer spending was not a precursor to the recession. Indeed, this can be seen by the cumulative currentquarter forecast errors, which summed to a little more than -3 percentage points by 2001:Q1 (the NBER business cycle peak).

Part of this strength in consumer expenditures was manifested after the terrorist attacks on September 11: To counteract the expected drop in

\footnotetext{
16 The share of consumer expenditures (current dollars) on nondurables has declined from about 46 percent in 1960 to about 30 percent currently. The other category, consumer durables, has varied much less, between 11 and around 14 percent.
} 


\section{Changing History: The 2001 Annual Revision to the NIPAs}

Each year, typically in late July, the Bureau of Economic Analysis releases revised estimates of the national income and product accounts (NIPAs). These revisions usually incorporate updated source data, but sometimes they also incorporate methodological changes. ${ }^{1}$ Examples of the latter include the decision in October 1999 to classify business purchases of software as a fixed investment (rather than treat them, as before, as an intermediate expense). These annual revisions can dramatically alter the growth of NIPA data over the previous three-year period and, hence, perceptions of the economy's strength on the part of financial markets and policymakers.

Prior to the July 2002 annual revision, some economists were puzzled by the decision of the NBER Business Cycle Dating Committee to date the peak of the 1991-2001 expansion as March 2001. This was especially true given that real GDP growth remained positive during the first two quarters of 2001, only to turn negative during the third quarter of 2001, when the September 11 terrorist attacks shut down financial markets and a significant part of the nation's transportation system for several days. The economic importance of the terrorist attacks was seen in a survey of business economists by the National Association for Business Economics in February 2002.2 According to this survey, the terrorist attacks were cited as the most important reason for the expansion's demise, which may explain why there was considerable disagreement between the NBER Business Cycle Dating Committee and other economists regarding the date of the recession's onset. Indeed, in the November 26, 2001, press release announc-

\footnotetext{
1 See Fixler and Grimm (2003).

2 Allyn (2002).
}

\section{Figure B1}

Real GDP Growth: Pre- and Post-July 2002

Percent Change, Annualized Growh

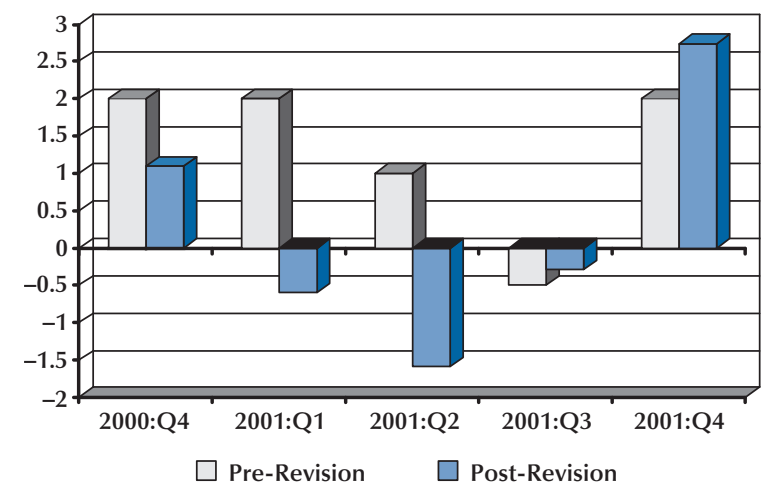

ing the business cycle peak, the Committee said that "before the attacks, it is possible that the decline in the economy would have been too mild to qualify as a recession. The attacks clearly deepened the contraction and may have been an important factor in turning the episode into a recession." 3

But the revised NIPA data released in July 2002 seemed to confirm the wisdom of the Committee's decision. The revision showed that the economy actually contracted during the first three quarters of 2001 (see figure), which correlates with the Committee's decision to date the peak as March 2001. Moreover, this annual revision seems to confirm the wisdom of the Committee's decision to not look at the behavior of real GDP growth when dating peaks and troughs. In fact, the NBER has stated that monthly nonfarm payroll employment "is probably the single most reliable indicator."

3 See < http://www.nber.org/cycles/november2001/> 


\section{Table 4}

\section{Current-Quarter Forecasts and Forecast Errors for Major NIPA Series}

2000:Q1 2000:Q2 2000:Q3 2000:Q4 2001:Q1 2001:Q2 2001:Q3 2001:Q4 2002:Q1

\begin{tabular}{|c|c|c|c|c|c|c|c|c|c|}
\hline \multicolumn{10}{|l|}{ Real GDP } \\
\hline $\begin{array}{l}\text { Current-quarter } \\
\text { forecast }\end{array}$ & 3.9 & 4.1 & 2.9 & 2.9 & 0.7 & 1.0 & 1.6 & -1.3 & 2.6 \\
\hline Real-time estimate & 5.4 & 5.3 & 2.4 & 1.1 & 1.3 & 0.2 & -1.1 & 1.4 & 5.6 \\
\hline Current-quarter error & -1.5 & -1.2 & 0.5 & 1.8 & -0.6 & 0.8 & 2.7 & -2.7 & -3.0 \\
\hline $\begin{array}{l}\text { Current-quarter } \\
\text { cumulative error }\end{array}$ & -1.5 & -2.7 & -2.2 & -0.4 & -1.0 & -0.2 & 2.5 & -0.2 & -3.2 \\
\hline \multicolumn{10}{|l|}{ Real PCE } \\
\hline $\begin{array}{l}\text { Current-quarter } \\
\text { forecast }\end{array}$ & 4.8 & 3.8 & 3.5 & 3.3 & 2.1 & 1.7 & 2.4 & 1.9 & 1.0 \\
\hline Real-time estimate & 7.5 & 2.9 & 4.5 & 2.8 & 2.9 & 2.5 & 1.1 & 6.0 & 3.2 \\
\hline Current-quarter error & -2.7 & 0.9 & -1.0 & 0.5 & -0.8 & -0.8 & 1.3 & -4.1 & -2.2 \\
\hline $\begin{array}{l}\text { Current-quarter } \\
\text { cumulative error }\end{array}$ & -2.7 & -1.8 & -2.8 & -2.3 & -3.1 & -3.9 & -2.6 & -6.7 & -8.9 \\
\hline \multicolumn{10}{|l|}{ Real BFI } \\
\hline $\begin{array}{l}\text { Current-quarter } \\
\text { forecast }\end{array}$ & 11.5 & 7.1 & 13.0 & 9.3 & 3.3 & -6.0 & -6.5 & -16.5 & -0.4 \\
\hline Real-time estimate & 25.2 & 14.6 & 7.8 & -0.6 & 2.1 & -14.6 & -9.3 & -13.1 & -8.2 \\
\hline Current-quarter error & -13.7 & -7.5 & 5.2 & 9.9 & 1.2 & 8.6 & 2.8 & -3.4 & 7.8 \\
\hline $\begin{array}{l}\text { Current-quarter } \\
\text { cumulative error }\end{array}$ & -13.7 & -21.2 & -16.0 & -6.1 & -4.9 & 3.7 & 6.5 & 3.1 & 10.9 \\
\hline \multicolumn{10}{|l|}{ Real RFI } \\
\hline $\begin{array}{l}\text { Current-quarter } \\
\text { forecast }\end{array}$ & 10.0 & 1.5 & -13.2 & -2.9 & -6.2 & -0.3 & -3.3 & -8.1 & -2.0 \\
\hline Real-time estimate & 5.2 & 0.0 & -10.5 & -3.4 & 2.9 & 5.8 & 2.5 & -5.0 & 14.6 \\
\hline Current-quarter error & 4.8 & 1.5 & -2.7 & 0.5 & -9.1 & -6.1 & -5.8 & -3.1 & -16.6 \\
\hline $\begin{array}{l}\text { Current-quarter } \\
\text { cumulative error }\end{array}$ & 4.8 & 6.3 & 3.6 & 4.1 & $-\mathbf{5 . 0}$ & -11.1 & -16.9 & -20.0 & -36.6 \\
\hline
\end{tabular}

sales, automobile manufacturers implemented special financing incentives, as light vehicle (passenger cars and light trucks) sales surged to a near-record pace of 21.1 million units (seasonally adjusted annual rate) in October. As a result, real consumer expenditures on motor vehicles and parts contributed 1.88 percentage points to fourth-quarter real GDP growth ( 2.7 percent), the largest contribution since the first quarter of 1971 (3.66 percentage points). Also helping to bolster real PCE growth was an upswing in purchases of non-automotive household durables.

What kept consumer spending relatively strong during the recession? Two factors stand out. First, these discretionary consumer purchases likely were boosted by the run-up in household wealth during the 1990s. Second, short-term interest rates were falling sharply prior to the onset of the recession, which helped to spur purchases of household durables (Figure 2). Typically, short-term interest rates, as viewed by yields on 3-month Treasury bills, peak about two months prior to the NBER peak. This time around, as seen in the upper portion of Figure 2, short-term interest rates peaked about four months prior to the onset of the recession (March 2001). A low, stable inflation rate may have been key in spurring subsequent aggressive reductions in the FOMC's intended federal funds rate target after the onset of the recession in 2001 . 


\section{Table 4 cont'd}

\section{Current-Quarter Forecasts and Forecast Errors for Major NIPA Series}

2000:Q1 2000:Q2 2000:Q3 2000:Q4 2001:Q1 2001:Q2 2001:Q3 2001:Q4 2002:Q1

\begin{tabular}{|c|c|c|c|c|c|c|c|c|c|}
\hline \multicolumn{10}{|l|}{ Real net exports } \\
\hline $\begin{array}{l}\text { Current-quarter } \\
\text { forecast }\end{array}$ & -360.1 & -384.6 & -418.6 & -427.3 & -440.3 & -417.5 & -412.2 & -410.0 & -439.4 \\
\hline Real-time estimate & -372.9 & -408.6 & -425.0 & -442.9 & -411.9 & -410.5 & -408.1 & -418.5 & -443.7 \\
\hline Current-quarter error & 12.8 & 24.0 & 6.4 & 15.6 & -28.4 & -7.0 & -4.1 & 8.5 & 4.3 \\
\hline $\begin{array}{l}\text { Current-quarter } \\
\text { cumulative error }\end{array}$ & 12.8 & 36.8 & 43.2 & 58.8 & 30.4 & 23.4 & 19.3 & 27.8 & 32.1 \\
\hline \multicolumn{10}{|l|}{ Nonfarm productivity } \\
\hline $\begin{array}{l}\text { Current-quarter } \\
\text { forecast }\end{array}$ & 1.6 & 2.8 & 2.0 & 1.3 & -0.8 & 1.7 & 2.1 & 1.9 & 4.1 \\
\hline Real-time estimate & 2.4 & 5.3 & 3.8 & 2.4 & -0.1 & 2.5 & 2.7 & 3.5 & 8.6 \\
\hline Current-quarter error & -0.8 & -2.5 & -1.8 & -1.1 & -0.7 & -0.8 & -0.6 & -1.6 & -4.5 \\
\hline $\begin{array}{l}\text { Current-quarter } \\
\text { cumulative error }\end{array}$ & -0.8 & -3.3 & -5.1 & -6.2 & -6.9 & -7.7 & -8.3 & -9.9 & -14.4 \\
\hline \multicolumn{10}{|l|}{ GDP price inflation } \\
\hline $\begin{array}{l}\text { Current-quarter } \\
\text { forecast }\end{array}$ & 2.0 & 2.3 & 2.2 & 2.2 & 2.4 & 2.4 & 1.8 & 1.5 & 1.4 \\
\hline Real-time estimate & 2.7 & 2.6 & 1.9 & 1.9 & 3.2 & 2.2 & 2.1 & -0.3 & 1.0 \\
\hline Current-quarter error & -0.7 & -0.3 & 0.3 & 0.3 & -0.8 & 0.2 & -0.3 & 1.8 & 0.4 \\
\hline $\begin{array}{l}\text { Current-quarter } \\
\text { cumulative error }\end{array}$ & -0.7 & -1.0 & -0.7 & -0.4 & -1.2 & -1.0 & -1.3 & 0.5 & 0.9 \\
\hline
\end{tabular}

NOTE: The Blue Chip Econometric Detail estimates are published in the March, June, September, and December issues of BCEI dated the 10th of each month. For example, in the March issue, the current quarter forecast would be the forecast for real GDP growth in the first quarter. The real-time estimate of first-quarter real GDP growth was published in the June issue. The forecast error is defined as forecasted growth less actual growth.

SOURCE: $B C E D$, various issues.

\section{Residential Construction}

Real RFI typically turns down about 11 months before the business cycle peak, as rising interest rates (Figure 2) slow the pace of housing starts and new home sales. In similar fashion, the growth of real RFI was weakening significantly prior to the 2001 recession. Hence, one potential cause of the 2001 recession may have been a shock to the residential housing sector. Table 4 shows that forecasters generally were surprised by the magnitude of the decline in housing construction in 2000. By the fourth quarter of 2000, the cumulative forecast error for real RFI was a little more than 4 percentage points.

The unexpected decline in housing investment prior to the March 2001 business cycle peak may have resulted from rising interest rates. Conventional mortgage interest rates rose from about 6.75 percent in December 1998 to about 8.5 percent in April 2000; over the same period, the 12-month percent change in the core PCE chain-type price index rose only from 1.6 percent to 1.9 percent. The rise in nominal and real interest rates corresponded with a more restrictive monetary policy: From June 1999 to May 2000 , the FOMC increased its intended federal funds target from 4.75 percent to 6.50 percent. ${ }^{17}$ Moreover, as seen in the bottom portion of Figure 2, longterm Treasury rates were at historically high levels

${ }^{17}$ From June 1999 to June 2000, the real federal funds target rate, defined as the nominal rate less the 12 -month change in the core PCE, rose about 150 basis points, nearly as much as the 175 -basispoint increase in the nominal rate. 


\section{Figure 2}

\section{Movements of Short- and Long-Term Interest Rates During the 2001 Recession Relative to Previous Post-World War II Recessions}

3-Month Treasury Bill Rate

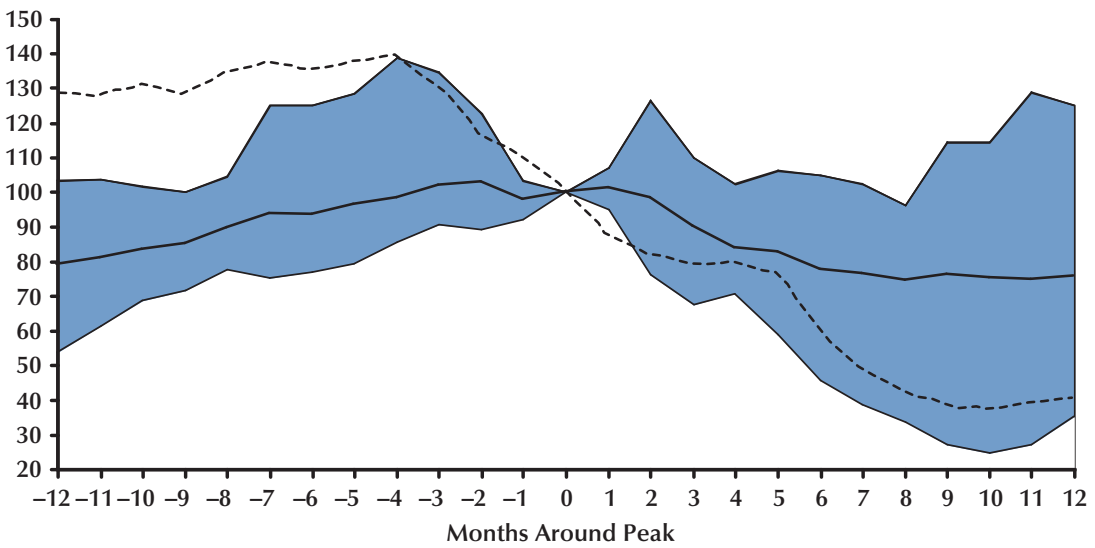

10-Year Treasury Bond Rate

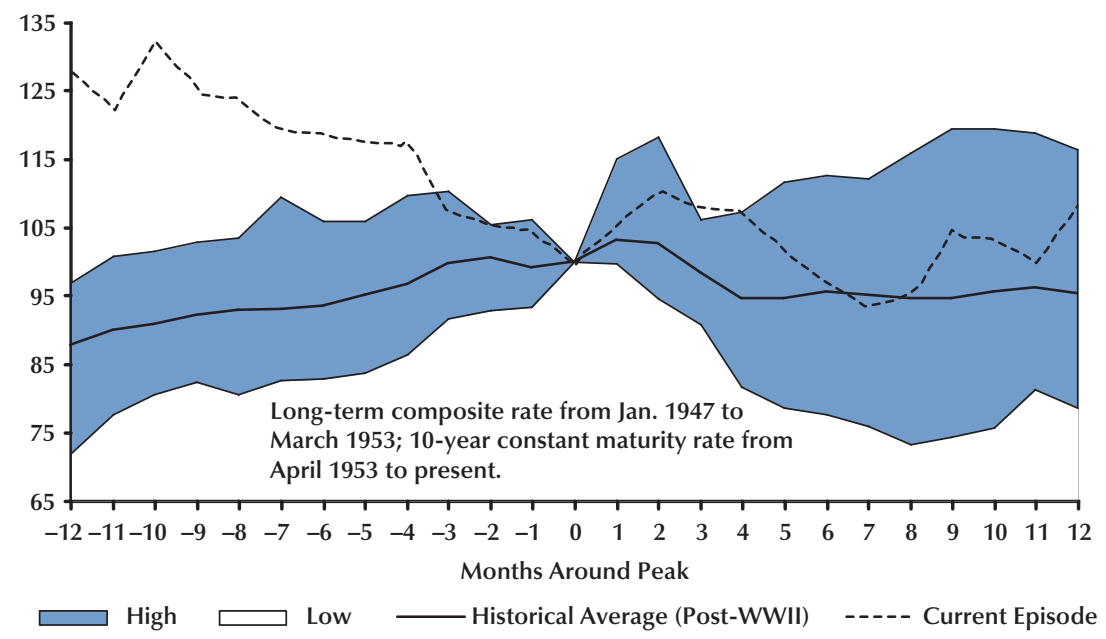

NOTE: The range of previous cycles denoted by the shaded areas excludes the 2001 recession and recovery.

(relative to previous postwar periods) prior to the 2001 business cycle peak.

Ironically, an unexpected decline in RFI may have helped trigger the onset of the recession; it also was an important factor tempering the severity of the 2001 recession. This can be seen in Table 4 as an abrupt switch from cumulative positive forecast errors for RFI growth to large cumulative negative forecast errors. In contrast with the typical pattern of growth after the business cycle peak, RFI strengthened in late 2000 and into the first two quarters of the recession. Referring back to Figure 2 helps to explain why. Yields on 10-year government securities usually top out about one month after the peak, but this time long-term rates peaked 10 months before the March 2001 business cycle peak. With mortgage interest rates also falling sharply, and real income growth remaining relatively strong (see Table 2), the housing sector benefited significantly. 


\section{International Trade}

Another factor that may have helped push the economy into a recession was an unexpected decline in real net exports. During the 2001 recession, as seen in Table 2, real exports of goods and services fell about 10 percent, which was substantially larger than the average post-World War II recession decline of roughly 0.75 percent. There were two factors working against U.S. exports leading up to the recession. The first of these was an appreciation of the trade-weighted value of the U.S. dollar. After falling nearly 5 percent from August 1998 to August 1999, the real value of the U.S. dollar began to rise shortly thereafter. ${ }^{18}$ By October 2000, the dollar was up nearly 13 percent from a year earlier. In addition to a price effect (an appreciation of the trade-weighted value of the dollar), growth of U.S. exports was tempered by a worldwide slowdown in economic activity, as world output growth slowed from 4.7 percent in 2000 to 2.3 percent in $2001 .{ }^{19}$ The decline in exports during the 2001 recession relative to 1998-2000 was most pronounced in non-automotive capital goods and consumer goods and travel and transportation services. The largest percentage-point declines in U.S. real exports were generally for those destined for Asia: South Korea (-58.4 percent), Taiwan (-37.3 percent), and Japan (-37.1 percent).

Table 4 shows that the Blue Chip forecasting model $(B C E D)$ significantly underestimated the decline in real net exports during 2000. In real dollars, the average quarterly error was about $\$ 15$ billion, or about 3.5 percent of the average value of real net exports over these four quarters. ${ }^{20}$ The current-quarter cumulative forecast error was nearly $\$ 59$ billion, or a little more than 14 percent of the average forecasted value of real net exports over these four quarters - although the Blue Chip model subsequently over-predicted the decline in real net exports during the recession.

\section{Business Investment}

Swings in business inventories typically account for a large percentage of the decline in output during

\footnotetext{
${ }^{18}$ This refers to the Federal Reserve Board's trade-weighted major currency index. The U.S. dollar is measured against currencies of the euro area (12 countries) and 6 additional countries. The real value uses the foreign consumer price indices to deflate the spot exchange rates.

${ }^{19}$ International Monetary Fund (2003).

20 The percentage error for real net exports is the current-quarter error divided by the actual value for that quarter.
}

a recession. As with most downturns, an unintended accumulation of business inventories relative to sales also preceded the 2001 recession. What was different this time is that the imbalance between inventories and sales was outside the range of previous downturns. As seen in Table 2, the peak-totrough decline in real private inventory investment was 3.6 percent, which surpassed the previous largest decline of 3.2 percent seen during the 1948-49 recession. But since forecasters were generally surprised by the strength of consumer spending during the recession, it appears that the decline in business inventories may have been more of a reflection of faster-than-expected growth of household expenditures (unexpectedly drawing down inventories) rather than planned reductions in inventories that filtered back into production cuts at manufacturers. However, it is also clear that the response to September 11 by automotive manufacturers led to a sizable decline in auto inventories in the fourth quarter of 2001.21

The largest component of business investment is fixed investment (expenditures on capital goods and structures). BFI is also one of the most volatile indicators of business activity, and it usually accounts for a large percentage of the decline in output during the average recession. Table 2 shows that the 2001 recession was fairly typical in terms of business capital spending. For example, real BFI fell 8 percent in the 2001 recession, only modestly more than the average downturn (7.6 percent). Although the decline in real equipment and software expenditures ( 7.3 percent) was somewhat smaller than average (9.7 percent), the decline in business structures (9.9 percent) was significantly larger than average (4.3 percent).

The pattern of BFI spending before the business cycle peak was consistent with previous episodes in that, on average, growth of BFI turns negative about one quarter prior to the peak. As seen in Table 4, this was true prior to the 2001 recession. But as Figure 3 shows, this only held true for business expenditures on information processing equipment and software (hereafter high-tech equipment). Business investment in commercial structures and industrial equipment reached its peak concurrent with the NBER-dated business cycle peak; on the other hand, spending on transportation equipment

\footnotetext{
21 The real change in private inventories was $-\$ 98.4$ billion in the fourth quarter of 2001 . Of this, $\$ 33.5$ billion was attributed to the change in real private automotive inventories.
} 


\section{Figure 3}

\section{Components of Real Business Fixed Investment}

Index, 1998:Q1 = 1.0
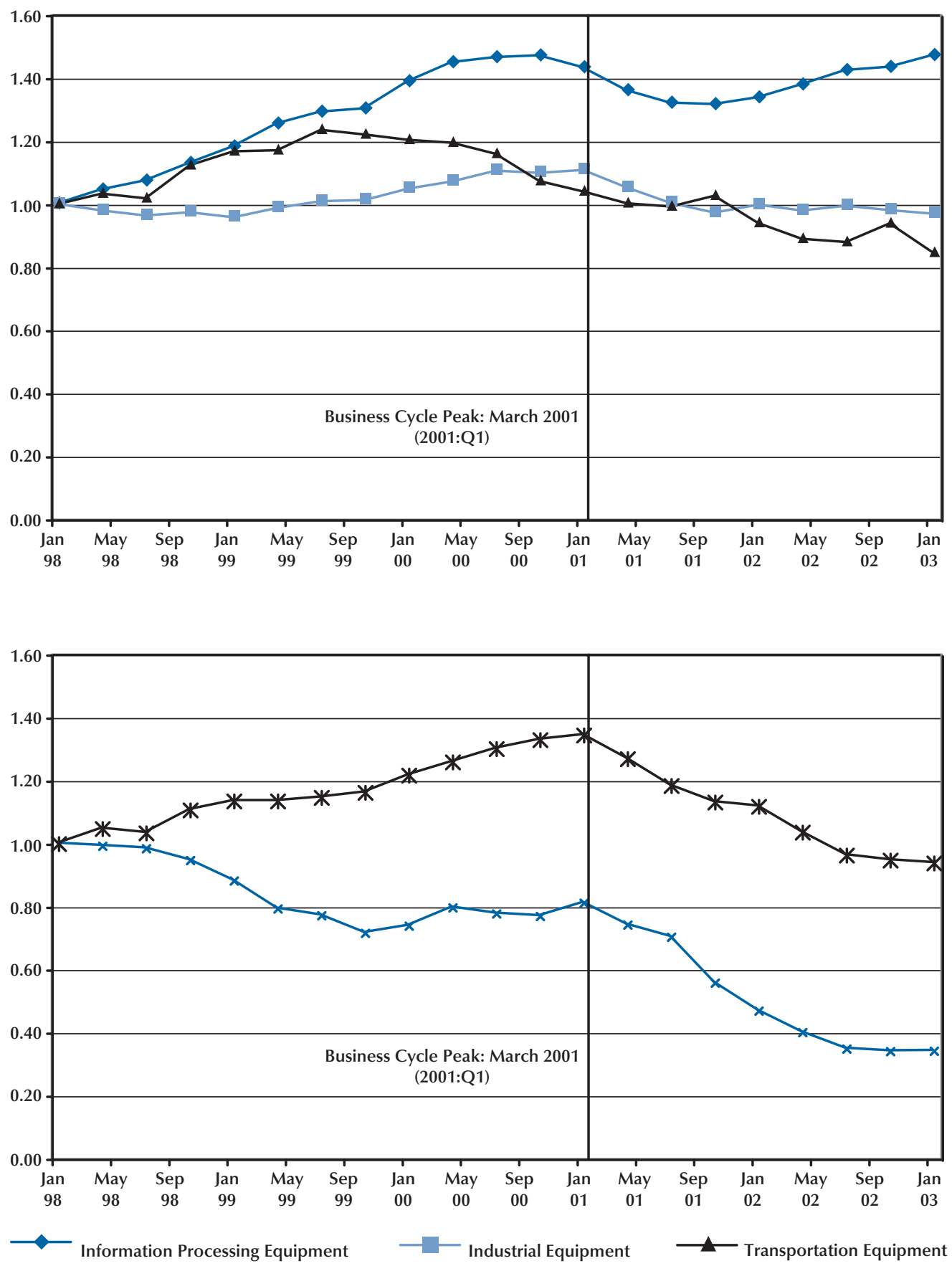

$\longrightarrow$ Industrial Structures $\longrightarrow$ Commercial Structures 
peaked much earlier (1999:Q3) and industrial structures, although rebounding modestly from 2000:Q2 through 2001:Q1, remained below its level seen three years earlier. The weakness in business commercial structures may have been exacerbated by overbuilding. In the third quarter of 2000 , the national commercial office vacancy rate (first reported in 1986:Q1) fell to a record low of 7.7 percent, while vacancy rates for industrial structures were little changed since the start of the business expansion in March 1991 (averaging around 8 percent). By 2003:Q1, the commercial vacancy rate had risen to a nine-year high of 16.4 percent and real fixed investment in commercial structures continued to decline. 22

Table 4 shows that Blue Chip forecasters significantly under-predicted the strength of real BFI over the first half of 2000: The forecast error over this two-quarter period averaged 10.6 percentage points. Hence, perhaps the most significant shock that led to the 2001 recession was the unexpected decline in real BFI. Although the pace of BFI growth was clearly slowing, forecasters responded to these large negative errors by raising their projected growth over the second half of 2001. The result was the opposite: relatively large positive errors. Although fairly sizable negative cumulative forecast errors continued into 2001:Q1, the persistent overestimation by forecasters of the strength of BFI spending caused these cumulative errors to become significantly positive by 2002:Q1. It thus appears that forecasters were surprised not only by the sudden decline in BFI, but by the persistence of the decline.

One factor that may have spurred tremendous growth of business expenditures on commercial structures and real information processing equipment and software late in the expansion was the sharp rise in equity prices, which lowered the cost of capital to firms. ${ }^{23}$ Presumably, the converse holds

\footnotetext{
22 The source for the national industrial vacancy rate is CB Richard Ellis; this measure of industrial vacancy rates begins in the first quarter of 1981.

${ }^{23}$ Caballero and Hammour (2002) argue that the rapid increase in stock prices in the latter part of the 1990s arose in part from the "emerging information technology sector" (investment boom) and the onset of fiscal surpluses. They argue that the fiscal surpluses may have arisen from the stock market boom and also helped fuel further investment by increasing aggregate saving. Tevlin and Whelan (2003) find that accelerated rates of depreciation and rapid rates of declines for prices of equipment explain much of the high-tech investment boom in the 1990s. They also argue that conventional models that do not use a disaggregated approach (high-tech and non-high-tech investment) thus could not account for the boom-nor, presumably, the bust.
}

as well: Declines in equity prices raise the cost of capital and slow the growth of capital expenditures. Thus, although equity prices topped off well before the peak in high-tech or commercial structures, falling stock prices beginning in 2000 probably caused firms to reassess the feasibility of many planned outlays and, ultimately, delay or cancel several projects. ${ }^{24}$ This is consistent with the growth of real BFI after the first quarter of 2000. Evidently, falling long-term rates were not a significant enough inducement to cause firms to increase planned outlays (see Figure 2). Hence, the timing of the declines in real BFI and the Nasdaq stock price index suggests some causation-if one believes the aforementioned cost-of-capital story that helped fuel the investment boom. It is also consistent with the timing of the large positive fixed investment forecast errors over the second half of 2000.

For computer equipment and software, an additional factor might have been precautionary capital expenditures by firms to eliminate Y2K computer glitches. But the largest potential Y2K-related investment contribution to real GDP growth probably occurred during the 1997-99 period, when expenditures on these goods were estimated to have contributed about 0.37 percentage points to real output growth, whereas total high-tech expenditures continued to increase strongly into the first half of 2000.25

\section{Productivity and Prices}

As seen in Table 2, nonfarm labor productivity rose 2.2 percent, more than a percentage point faster than during the average postwar recession. Strong labor productivity growth also helped to keep real disposable personal income growth positive during the recession ( 0.37 percent), rather than declining slightly as is typically the case. Hence, helping to underpin the strength of real consumer spending during the recession was relatively strong growth of nonfarm labor productivity. Table 4 shows that the relatively strong labor productivity growth was quite a surprise to forecasters. Over this ninequarter period, forecasters underestimated quarterly labor productivity growth rates in each quarter. By 2002:Q1 the cumulative forecast error was 14.4 percentage points, an average of 1.6 percentage points per quarter. Recent empirical work on the

\footnotetext{
${ }^{24}$ The Nasdaq and S\&P 500 reached a peak in the first quarter of 2000 ; the Wilshire 5000 peaked in the third quarter of 2000.

${ }^{25}$ See Kliesen (2003).
} 
sources of this productivity shock suggests much of it stemmed from the high-tech investment boom of the 1990s. ${ }^{26}$

Faster than expected productivity growth also helped to minimize growth of unit labor costs and aggregate inflation pressures. Although forecasters were surprised by the persistence of strong productivity growth, their inflation forecast errors were much smaller: From 2000:Q1 to 2002:Q1, the cumulative GDP inflation forecast error was 0.9 percentage points, or about zero when averaged over this period. By contrast, the cumulative real GDP forecast error was -3.2 percentage points.

\section{CONCLUSION}

When viewed across the expanse of postWorld War II recessions, the 2001 recession was both relatively mild and of comparatively short duration. The 2001 recession and recovery was also unusual in several respects. First, in contrast to the typical downturn, spending on consumer durable goods and new residential housing continued to grow throughout the recession. The strength of these relatively interest-sensitive sectors reflected the steep declines in short- and long-term interest rates that started well before the onset of the recessionanother distinguishing difference. Second, the 2001 recession was also notable for the sharp decline in exports and business investment in structures and inventories. Further, the declines in business capital spending were probably magnified by the sharp declines in equity prices during the recession, which helped to raise firms' financial cost of capital.

Identifying a cause of the recession is difficult. Using real-time forecast errors from Macroeconomic Advisers' forecasting model, which incorporates the Blue Chip Consensus forecast, it appears that shocks to investment by businesses and households were important factors. Another significant factor appears to be the unexpected declines in real net exports in 2000, which likely exacerbated the shock to the capital goods sector. Offsetting these shocks were unexpectedly large increases in labor productivity growth. This productivity shock helped to keep growth of real disposable income at an elevated rate during the recession.

\footnotetext{
${ }^{26}$ See Jorgenson, Ho, and Stiroh (2002) and Oliner and Sichel (2002).
}

\section{REFERENCES}

Allyn, Maureen F. "NABE Outlook Panel: America Is on the Threshold of Sustained Recovery." National Association for Business Economics Outlook, February 2002.

Balke, Nathan S. and Wynne, Mark A. "Are Deep Recessions Followed by Strong Recoveries? Results for the G-7 Countries." Applied Economics, July 1996, 28(7), pp. 889-97.

Blanchard, Olivier J. "Consumption and the Recession of 1990-1991." American Economic Review, May 1993, 83(2), pp. 270-74 (Papers and Proceedings of the 105th Annual Meeting of the American Economic Association).

Boldin, Michael D. "Dating Turning Points in the Business Cycle." The Journal of Business, January 1994, 67(1), pp. 97-131.

Caballero, Ricardo J. and Hammour, Mohamad L. "Speculative Growth." NBER Working Paper No. w9381, National Bureau of Economic Research, December 2002.

Chauvet, Marcelle and Piger, Jeremy M. "Identifying Business Cycle Turning Points in Real Time.” Federal Reserve Bank of St. Louis Review, March/April 2003, 85(2), pp. 47-61.

Fixler, Dennis J. and Grimm, Bruce T. "Revisions, Rationality, and Turning Points in GDP." Presented at the 115th Annual Meeting of the American Economic Association, "Tracking the Turning Points in the Economy." Washington, DC: 3-5 January 2003.

Friedman, Milton. "Monetary Studies of the National Bureau," in The National Bureau Enters Its 45th Year, 44th Annual Report of the National Bureau of Economic Research, 1964, pp. 7-25.

Fuhrer, Jeffrey C. and Schuh, Scott. "Beyond Shocks: What Causes Business Cycles? An Overview." Presented at the 42nd Annual Economic Conference of the Federal Reserve Bank of Boston, 1998.

Hall, Robert E. "Macro Theory and the Recession of 19901991." American Economic Review, May 1993, 83(2), pp. 275-79 (Papers and Proceedings of the 105th Annual Meeting of the American Economic Association).

Hamilton, James D. "A New Approach to the Economic Analysis of Nonstationary Time Series and the Business Cycle." Econometrica, March 1989, 57(2), pp. 357-84. 
Hansen, Gary D. and Prescott, Edward C. "Did Technology Shocks Cause the 1990-1991 Recession?" American Economic Review, May 1993, 83(2), pp. 280-86 (Papers and Proceedings of the 105th Annual Meeting of the American Economic Association).

International Monetary Fund. World Economic Outlook: Growth and Institutions. Washington, DC: April 2003.

Jorgenson, Dale W.; Ho, Mun S. and Stiroh, Kevin J. "Projecting Productivity Growth: Lessons from the U.S. Growth Resurgence.” Federal Reserve Bank of Atlanta Economic Review, Third Quarter 2002, 87(3), pp. 1-13.

Kliesen, Kevin L. "Was Y2K Behind the Business Investment Boom and Bust?" Federal Reserve Bank of St. Louis Review, January/February 2003, 85(1), pp. 31-42.

Koenig, Evan F.; Siems, Thomas F. and Wynne, Mark A. "New Economy, New Recession." Federal Reserve Bank of Dallas Southwest Economy, March/April 2002, O(2), pp. 11-16.

Lansing, Kevin J. "Growth in the Post-Bubble Economy." Federal Reserve Bank of San Francisco Economic Letter, No. 2003-17, 20 June 2003.

Nordhaus, William D. "Puzzles About the American Economy in the Current Recession and Recovery." Unpublished manuscript, Yale University, 15 April 2002.

Oliner, Stephen D. and Sichel, Daniel E. “Information Technology and Productivity: Where Are We Now and Where Are We Going?" Federal Reserve Bank of Atlanta Economic Review, Third Quarter 2002, 87(3), pp. 15-44.

Taylor, John B. "Monetary Policy and the Long Boom." Federal Reserve Bank of St. Louis Review, Novemberl December 1998, 80(6), pp. 3-11.

Tevlin, Stacey and Whelan, Karl. "Explaining the Investment Boom of the 1990s." Journal of Money, Credit, and Banking, February 2003, 35(1), pp. 1-22.

Walsh, Carl E. "What Caused the 1990-1991 Recession?" Federal Reserve Bank of San Francisco Economic Review, 1993, O(1), pp. 33-48.

Zarnowitz, Victor. "Business Cycles: Theory, History, Indicators, and Forecasting," in NBER Studies in Business Cycles. Volume 27. Chicago: University of Chicago Press, 1992, pp. 77-124 
Kliesen

RE V IE W 